\title{
KUALITAS KEPEMIMPINAN KEPALA MADRASAH PEREMPUAN DI LINGKUNGAN PONDOK PESANTREN
}

\author{
LEADERSHIP QUALITIES OF FEMALE MADRASA LEADERS IN PONDOK PESANTREN \\ Nurhilaliati \\ Univeritas Islam Negeri Mataram \\ email: nurhilaliati@uinmataram.ac.id
}

Naskah Diterima: 02 Januari 2019; Direvisi: 05 Maret 2019; Disetujui: 22 April 2019

\begin{abstract}
This study is focused on efforts to assess quality and predict the leadership prospects of female madrasa leaders in pondok pesantren in West Lombok Regency. Using the qualitative-descriptive approach, the author seeks to express the quality of women's leadership based on perceptions, attitudes, and behaviors of some women in the position of head of the madrasa through interviews and observation. This study found that the leadership of female in madrasa can be categorized as having good quality. Based on the nine indicators used, there are seven indicators that appear in all research subjects, namely emotional maturity, objective, perceptive, adaptation, initiative, creativity, and communication skills. Responsibility indicators do not appear optimally in one subject of the study. Likewise, indicators of confidence. Women have good prospects to be in the leadership position because of quality. There is no significant rejection of female leaders, and there is no differentiation of opportunities for women and men to become leaders, as long as they have the ability.
\end{abstract}

Keywords: Creativity; Emotional maturity; Initiative; Perceptive; Responsibility

\begin{abstract}
Abstrak
Kajian ini difokuskan pada upaya menilai kualitas dan memprediksi prospek kepemimpinan kepala madrasah perempuan di pondok pesantren di Kabupaten Lombok Barat. Menggunakan pendekatan kualitatif-deskriptif, karena penulis berupaya mengungkapkan kualitas kepemimpinan perempuan berdasarkan persepsi, sikap, dan perilaku dari beberapa perempuan pada posisi jabatan kepala madrasah yang berada di lingkungan pondok pesantren, melalui wawancara dan observasi. Kajian ini menemukan bahwa Kepemimpinan kepala madrasah perempuan di pondok pesantren dapat dikategorikan memiliki kualitas yang cukup baik. Berdasarkan sembilan indikator yang digunakan, terdapat tujuh indikator yang muncul pada semua subjek penelitian yaitu kedewasaan emosional, objektif, perseptif, adaptasi, inisiatif, kreativitas, dan skill berkomunikasi. Indikator tanggungjawab tidak muncul secara maksimal pada satu subjek penelitian. Demikian juga indikator percaya diri. Perempuan memiliki prospek yang baik untuk berada di posisi pimpinan karena adanya kualitas. Tidak ada penolakan signifikan terhadap pemimpin perempuan, dan tidak ada pembedaan kesempatan bagi perempuan dan laki-laki untuk menjadi pemimpin, selama memiliki kemampuan.
\end{abstract}

Kata kunci: Inisiatif; Kedewasaan emosional; Kreativitas; Perseptif; Tanggung jawab 


\section{PENDAHULUAN}

Budaya patriarki (Suralaga, 2003) yang dianut oleh sebagian besar penduduk dunia, telah melahirkan kenyataan dan persepsi yang berdampak terhadap pembedaan peran laki-laki dan perempuan dalam kehidupan sosial masyarakat. Selama waktu yang amat panjang, anatomi biologis yang berbeda antara laki-laki dan perempuan menjadi faktor utama dalam penentuan peran sosial keduanya. Laki-laki memegang peran utama dalam masyarakat karena dianggap lebih kuat, potensial dan produktif. Sementara perempuan yang mempunyai organ reproduksi, dianggap lebih lemah, kurang potensial dan tidak produktif.

$\begin{array}{ccc}\text { Telah } & \text { banyak } & \text { penelitian yang } \\ \text { menunjukkan bahwa, } & \text { meskipun secara }\end{array}$ kuantitas, jumlah perempuan yang menempati posisi sebagai pemimpin tidak sebanding dengan jumlah laki-laki, namun kualitas kepemimpinan mereka lebih disukai. Sebab perempuan yang menjadi pemimpin biasanya memiliki sikap transformasional, mengayomi, dan berbagi. Sedangkan laki-laki yang menjadi pemimpin pada umumnya memiliki sikap transaksional (Shanmugam, at al), (Bailey, 2014), (Anna G, 2016), structural, dan cenderung kaku. Terdapat perbedaan perempuan dan laki-laki dalam memimpin, dimana perempuan menunjukkan kualitas yang lebih baik terutama dalam bidang bisnis (Helgesen, 1995). Meskipun demikian, tidak banyak orang menyukai dipimpin oleh perempuan. Kondisi ini menjadi kesulitan bagi perempuan untuk menjadi pemimpin dan berhasil dalam peran kepemimpinannya di lingkungan yang didominasi oleh laki-laki (Eagly, 2007).

Perempuan kontemporer sekarang memiliki kesiapan yang lebih baik untuk memimpin dan memiliki kelebihan dibandingkan laki-laki. Hal ini selain karena tingkat pendidikan perempuan sudah sama dengan laki-laki, juga sudah terbuka kesempatan bagi mereka untuk mengaktualisasi diri, serta peningkatan keberdayaan perempuan yang sangat intens dilakukan dalam berbagai program pembangunan.

Pondok pesantren sebagai salah satu jenis lembaga pendidikan Islam di Indonesia, dapat dikatakan sebagai lembaga yang sangat unik. Pertama, pondok pesantren merupakan sebuah sub-kultur karena eksistensi pondok pesantren sebagai sebuah lembaga yang menyimpang dari pola kehidupan umum masyarakat di sekelilingnya (Wahid, 2010). Kedua, kepemimpinan pendidikan yang pada umumnya selalu memposisikan laki-laki sebagai pucuk pimpinan maupun jajaran pimpinan. Keadaan ini sadar atau tidak akan membangun opini bahwa pondok pesantren "tidak ramah" perempuan, dalam arti tidak memberikan kesempatan kepada perempuan untuk mengembangkan potensi dan mencoba kemampuannya dalam memimpin lembaga pendidikan semacam pondok pesantren. Pondok pesantren sebagai sebuah lembaga pendidikan Islam, dengan demikian, masih menyisakan masalah mendasar yang terkait dengan isu keadilan dan kesetaraan gender terkait pemberian kesempatan yang sama kepada laki-laki dan perempuan untuk memimpin (Mufidah, 2010).

Budaya pondok pesantren yang "melelaki" ini, dengan sendirinya akan membentuk opini bahwa "tidak (kurang) lumrah" ketika ada perempuan yang "memondok pesantren". Sepanjang sejarah pondok pesantren, peran perempuan terkait institusi ini hanyalah sebagai Bu Nyai, yang berkedudukan sebagai istri atau ibu dari Tuan Guru atau Kiai. Dalam kedua posisi tersebut, perempuan hanya memiliki ruang gerak yang terbatas dan tidak memiliki kewenangan dalam mengaktualisasi potensi dirinya. Betapapun besar peran yang dimainkan oleh $\mathrm{Bu}$ Nyai tersebut, tidak lantas akan mengubah anggapan masyarakat tentang ketokohan perempuan di lembaga ini. Capaian apapun yang dihasilkan perempuan, jika seperti ini, akan selalu dikait-lekatkan dengan siapa bapaknya, siapa suaminya, atau siapa keluarganya (dengan penekanan pada garis keturunan laki-laki) (Nurhilaliati, 2018).

Informasi yang diperoleh dari Kantor Kementerian Agama (Kemenag) Kabupaten Lombok Barat, bahwa di wilayah Lombok Barat NTB jumlah pondok pesantren aktif (dalam pengertian yang beragam) yang terdata adalah sebanyak 77 buah, dan jumlah madrasah (di luar madrasah negeri) berdasarkan jenjangnya adalah MI 95 sekolah, MTs 109 sekolah, dan MA 73 sekolah. 
Demikian juga wawancara dengan seorang informan (Fathurrahman), "seperti umumnya pondok pesantren lain di tanah air, hampir semua pondok pesantren di daerah ini digagas, didirikan, dikelola, dan diasuh oleh tuan guru atau kiai yang laki-laki”.

Informasi awal yang diperoleh dari Kantor Kemenag Kabupaten Lombok Barat, diketahui bahwa ada beberapa pondok pesantren yang memiliki madrasah yang dipimpin oleh perempuan. Madrasah yang dimaksud adalah MA As-Sulami Langko Lingsar, Mts As-Sulami Langko Lingsar, MTs Attarbiyah Addiniyah Gersik Kediri (al-Amin), MTs NW Selaparang Putri Kediri, MI Nurul Hakim Kediri, MA Darunnajah Duman Lingsar, dan MI Yusuf Abdul Satar Kediri.

Membandingkan data ini dengan data terkait jumlah keseluruhan pondok pesantren dan madrasah yang ada di dalamnya, menggiring pada sebuah asumsi bahwa terkait kepemimpinan. Pondok pesantren masih jauh dari kata responsif gender karena dari dua ratus lebih madrasah yang ada, hanya delapan madrasah yang dipimpin oleh kepala madrasah perempuan. Tentu saja ini menjadi sebuah ironi, mengingat gencarnya program nasional maupun internasional yang bertujuan untuk meningkatkan keberdayaan perempuan dalam segala bidang.

Fenomena kepemimpinan perempuan dalam konteks Pendidikan memang telah menjadi daya tarik tersendiri untuk diteliti lebih jauh. Studi yang dilakukan Coleman dkk (Bush, Tony; Coleman, 2006) menunjukkan para kepala sekolah dan para manajer senior perempuan di Inggris dan Wales, mengindikasikan kecenderungan berperilaku model kepemimpinan transformatif dan partisipatif. Studi lainnya tentang para kepala guru dan kepala sekolah perempuan di Amerika Serikat, Inggris Raya, Australia, Selandia Baru dan Kanada menunjukkan bahwa mereka tampil bekerja secara kooperatif dan memberdayakan koleganya serta memfungsikan team work secara efektif.

Kepribadian pemimpin perempuan sebagai sosok yang lebih supel, demokratis, perhatian, artistik, bersikap baik, cermat dan teliti, berperasaan, dan berhati-hati (Jirasinghe, 1996). Selain itu, mereka cenderung menjadi sosok pekerja tim, lengkap dan sempurna. Mereka juga mengidentifikasi diri dan mempersepsi dirinya sebagai sosok yang lebih rasional, rileks, keras hati, aktif, dan kompetitif.

Melihat perbedaan dan beberapa kelebihan yang dimiliki oleh pemimpin perempuan dibanding pemimpin laki-laki, ini menjadi salah satu indikator bahwa perempuan harus diberi kesempatan seluas-luasnya untuk mengembangkan potensi kepemimpinan yang ada pada dirinya. Sehingga ke depan kepemimpinan perempuan juga dapat dijadikan sebagai salah satu model yang dapat diterapkan dalam dunia kepemimpinan, bukan sematamata karena keharusan yuridis namun karena kelebihan dan kemampuannya.

\section{METODE PENELITIAN}

Penelitian ini menggunakan pendekatan kualitatif deskriptif (Stainback, 1988; Marshall, Catherine; Rossman, 1995; Sugiyono, 2010). Penelitian ini diharapkan dapat mengungkapkan serta memaparkan kualitas kepemimpinan perempuan berdasarkan persepsi, sikap, dan perilaku dari beberapa perempuan pada posisi jabatan kepala madrasah yang berada di lingkungan pondok pesantren.

Penelitian ini dilaksanakan dalam dua tahap. Tahap pertama dilakukan di Kantor Kemenag Kabupaten Lombok Barat untuk mencari data tentang jumlah kepala madrasah perempuan. Tahap kedua, yaitu penelitian terhadap delapan kepala madrasah perempuan di beberapa pondok pesantren yang sebelumnya dipilih secara purposive. Instrumen utama pengumpulan data dalam penelitian ini adalah peneliti sendiri. Oleh karena itu, teknik utama yang digunakan dalam pengumpulan data penelitian adalah teknik indepth interview (wawancara mendalam), yang dibantu dengan observasi non-partisipatif dan dokumentasi.

\section{HASIL DAN PEMBAHASAN}

Kepemimpinan merupakan salah satu fungsi manajemen, memiliki peranan penting dalam mencapai tujuan organisasi. Dengan demikian, pemimpin merupakan faktor penentu keberhasilan ataupun kegagalan suatu 
organisasi. Kepemimpinan yang akan modern, serta bersedia memberikan mencapai keberhasilan tentu saja yang kesejahteraan dan kebahagiaan kepada memiliki kualitas yang baik, yaitu yang bawahan dan masyarakat luas (Veithzal Rivai, mampu mengelola dan menggerakkan 2009). organisasi sesuai dengan asas-asas manajemen

Tabel 1. Temuan Penelitian terkait kualitas kepala madrasah perempuan di lembaga pendidikan Islam di Lombok Barat

\begin{tabular}{|c|c|}
\hline Indikator & Temuan penelitian \\
\hline Tanggung Jawab & $\begin{array}{l}\text { 1. Merasa terpanggil untuk memperbaiki kondisi madrasah } \\
\text { 2. Melakukan pembinaan terhadap seluruh warga madrasah } \\
\text { 3. Memberikan keteladan kepada seluruh warga madrasah dengan } \\
\text { terus belajar dan menambah wawasan serta mengajar dengan } \\
\text { baik } \\
\text { 4. Mengayomi seluruh warga madrasah } \\
\text { 5. Bekerja sama dengan berbagai pihak untuk mewujudkan } \\
\text { madrasah yang berkualitas } \\
\text { 6. Alasan normatif. }\end{array}$ \\
\hline Kedewasaan Emosional & $\begin{array}{l}\text { 1. Sabar dan tidak mudah putus asa ketika menghadapi kendala } \\
\text { 2. Melaksanakan tugas dan kewajiban secara seimbang } \\
\text { 3. Bersikap tabah ketika menghadapi kegagalan } \\
\text { 4. Mendahulukan kepentingan orang banyak dari kepentingan } \\
\text { pribadi } \\
\text { 5. Bersikap proporsional dan situasional } \\
\text { 6. Ikhlas berbagi. }\end{array}$ \\
\hline Objektif & $\begin{array}{l}\text { 1. Introspeksi diri. Bermusyawarah ketika terjadi perbedaan } \\
\text { pendapat dalam suatu hal terkait madrasah } \\
\text { 2. Melakukan mediasi terhadap pihak yang bertikai } \\
\text { 3. Mendengarkan kedua belah pihak baru memutuskan sesuatu } \\
\text { 4. Bersikap tegas. }\end{array}$ \\
\hline Perseptif & $\begin{array}{l}\text { 1. Melakukan interaksi dan komunikasi secara intensif dengan } \\
\text { seluruh warga madrasah } \\
\text { 2. Jika ada beberapa alternatif yang dihadapi, maka diterima semua } \\
\text { kemudian dilakukan seleksi dan terakhir baru diputuskan } \\
\text { 3. Objektif dalam sikap dan perilaku } \\
\text { 4. Memiliki sikap peduli (empati) terhadap warga madrasah } \\
\text { 5. Bersikap demokratis. }\end{array}$ \\
\hline Inisiatif & $\begin{array}{l}\text { 1. Berani bertindak sendiri ketika menghadapi situasi darurat, tetap } \\
\text { melakukan koordinasi dengan pihak terkait dalam kondisi } \\
\text { normal } \\
\text { 2. Bertanggung jawab atas sebuah tindakan atau keputusan } \\
\text { 3. Melakukan pertimbangan secara matang sebelum memutuskan } \\
\text { dan melakukan sesuatu. }\end{array}$ \\
\hline $\begin{array}{l}\text { Kemampuan } \\
\text { Berkomunikasi }\end{array}$ & $\begin{array}{l}\text { 1. Melakukan komunikasi secara lisan dan tertulis, namun lebih } \\
\text { didominasi komunikasi lisan } \\
\text { 2. Membangun suasana kekeluargaan dan tidak menjaga jarak } \\
\text { dengan seluruh warga madrasah } \\
\text { 3. Melakukan komunikasi non formal struktural } \\
\text { 4. Koordinatif dan koperatif } \\
\text { 5. Melakukan komunikasi banyak arah } \\
\text { 6. Menggunakan media sosial } \\
\text { 7. Keteladan. }\end{array}$ \\
\hline
\end{tabular}




\begin{tabular}{ll}
\hline \multicolumn{1}{c}{ Indikator } & \multicolumn{1}{c}{ Temuan penelitian } \\
\hline Percaya Diri & 1. Tiga orang dari kepala madrasah memiliki rasa percaya diri \\
yang sangat tinggi & 2. Tiga orang pernah merasakan tidak percaya diri dan sekarang \\
& sudah percaya diri \\
3. Satu orang tidak mempunyai rasa percaya diri.
\end{tabular}

Tabel 2. Capaian kepala madrasah perempuan di lingkungan pondok pesantren

\begin{tabular}{|c|c|}
\hline Nama madrasah & Capaian kepala madrasah \\
\hline MI Yusuf Abdussatar & $\begin{array}{l}\text { 1. Peningkatan jumlah peserta didik secara signifikan } \\
\text { 2. Kualitas SDM menjadi lebih baik } \\
\text { 3. Terbentuknya lembaga "Pra-MI" yaitu TK/R } \\
\text { 4. Pengembangan kompetensi entrepreneurship } \\
\text { 5. Aktif "menjemput bola" terkait penerimaan peserta didik baru } \\
\text { dengan cara pemberian seragam } \\
\text { 6. Memprioritaskan gaji guru. }\end{array}$ \\
\hline MA Darunnajah & $\begin{array}{l}\text { 1. Pembinaan berkelanjutan terhadap guru } \\
\text { 2. Mengembalikan ciri khas kepondokan } \\
\text { 3. Penerapan "open management" } \\
\text { 4. Pengadaan LCD dan pengharusan bagi setiap guru untuk dapat } \\
\text { mengoperasikannya } \\
\text { 5. Evaluasi secara berkala } \\
\text { 6. Rekreasi setiap akhir semester. }\end{array}$ \\
\hline MI Nurul Hakim & $\begin{array}{l}\text { 1. Peraturan tidak boleh merokok di kompleks madrasah } \\
\text { 2. Peraturan cara berpakaian terutama bagi perempuan (tidak boleh } \\
\text { memakai celana panjang) } \\
\text { 3. Pemberian reward pada guru berprestasi } \\
\text { 4. Kerjasama dengan stakeholders } \\
\text { 5. Melakukan evaluasi diri dan guru secara berkala } \\
\text { 6. Dipercaya sebagai ketua KKM } \\
\text { 7. Dipercaya sebagai rektor. }\end{array}$ \\
\hline MTs NW Selaparang Putri & $\begin{array}{l}\text { 1. Melakukan evaluasi diri dan guru secara berkala } \\
\text { 2. Melakukan tes dalam penerimaan guru baru } \\
\text { 3. Peraturan cara berpakaian. }\end{array}$ \\
\hline MTs As-Sullamy & $\begin{array}{l}\text { 1. Pembentukan "Raudatul Ilmi" } \\
\text { 2. Merapikan sistem } \\
\text { 3. Ekstrakurikuler diaktifkan dan dimaksimalkan lagi } \\
\text { 4. Pembentukan forum guru } \\
\text { 5. Rencana pembentukan sekolah inklusi (belum terlaksana karena } \\
\text { peserta didik difable tidak mencapai enam orang). }\end{array}$ \\
\hline MA As-Sullamy & Pembentukan forum diskusi guru \\
\hline MTs at-Tarbiyah & $\begin{array}{l}\text { 1. Melanjutkan dan memprioritaskan pelatihan guru } \\
\text { 2. Pengadaan sarana-prasarana belajar. }\end{array}$ \\
\hline
\end{tabular}

Realitas yang ditampilkan oleh kepemimpinan kepala madrasah perempuan di pondok pesantren di Kabupaten Lombok Barat, dianalisis dengan teori Psikologi Trait Theory of Leadership. Teori sifat ini mencoba memaparkan pemimpin dan kepemimpinan 
dilihat dari sifat-sifat yang ada atau melekat pada diri seseorang. Seseorang yang mempunyai sifat-sifat atau ciri-ciri sebagaimana yang dimaksudkan dalam pendekatan teori sifat inilah, dapat dikatakan pantas dan layak disebut sebagai pemimpin. Aktivitas dalam melaksanakan tugasnya sebagai pemimpin dengan sendirinya akan lekat dan terkait sekali dengan sifat-sifat yang dimilikinya.

Teori ini digunakan dalam penelitian ini untuk menjelaskan bahwa kepemimpinan kepala madrasah perempuan di pondok pesantren di Kabupaten Lombok Barat, memang didukung oleh sifat-sifat tertentu sehingga dapat menjalankan tugas dan fungsinya sebagai pemimpin, terutama dalam membangun hubungan baik dengan orang lain. Dengan kata lain, tugas dan fungsi kepemimpinan tidak dilaksanakan secara otoriter oleh para kepala madrasah perempuan, melainkan karena sifat atau kharisma yang dimilikinya.

Secara umum sifat-sifat yang harus dimiliki oleh seorang pemimpin itu, yaitu: (1) mempunyai dorongan yang kuat untuk bertanggung jawab atas tugas yang dipercayakan kepadanya; (2) teguh mempertahankan pekerjaan untuk memenuhi tujuan; (3) mempunyai dorongan yang kuat untuk menguji beragam inisiatifnya dalam situasi sosial; (4) percaya diri dan mempunyai perhatian yang penuh terhadap identitas pribadi anggota; (5) dapat menerima berbagai keputusan dan tindakan yang bahkan tidak menguntungkan dirinya; (6) dapat membawa dan menyerap semua hasrat dan keinginan anggota; (7) dapat bersikap toleran terhadap kegagalan dan frustasi; (8) mampu memengaruhi perilaku anggota, beradaptasi dengan struktur sosial, serta sistem interaksi (Muflihin, 2018).

Lebih jauh sifat-sifat yang harus dimiliki oleh seorang pemimpin, yaitu: (1) intelegensi. Tingkat intelegensi yang dimiliki oleh seorang pemimpin dapat membantu memberikan pilihan dan keputusan cerdas dalam menjalankan tugasnya; (2) inisiatif. Kemampuan inisiatif yang perlu dimiliki oleh pemimpin ini adalah kemampuan untuk bertindak sendiri dan mengatur tindakan- tindakan, dan kemampuan untuk melihat arah tindakan yang tidak terlihat oleh pihak lain; (3) energi atau rangsangan. Seseorang yang mempunyai energi banyak, kuat, dan sehat dianggap dapat menjadi pemimpin karena ia akan lebih bersemangat dan berkemampuan dalam mencapai tujuan yang telah ditetapkan; (4) kedewasaan emosional. Sifat kedewasaan yang dimiliki oleh seseorang berupa; dapat diandalkan (dependability), persistensi, dan objektivitas merupakan sifat yang layak dimiliki oleh calon pemimpin; (5) persuasif. Sifat pandai melakukan persuasif ini diperlukan bagi pemimpin dalam rangka mendapatkan persetujuan dengan anggota yang dipimpinnya; (6) skill komunikasi. Seorang yang mempunyai kepandaian dan kecakapan dalam berbicara dan menulis dengan tegas dan jelas dipandang mampu untuk mengemukakan pendapat, ide, dan gagasan kepada orang lain; (7) kepercayaan pada diri sendiri. Pemimpin yang memiliki rasa percaya diri tidak akan gampang dipengaruhi oleh orang lain. Percaya diri ini tentu saja terbangun dari kematangan kepribadian dan intelektual yang dimilikinya; (8) perseptif. Sifat ini berhubungan dengan kemampuannya untuk mendalami ciri-ciri dan kelakuan orang-orang lain, terutama bawahannya. Hal ini juga mencakup kemampuannya dalam memproyeksikan diri sendiri secara mental dan emosional ke dalam posisi orang lain; (9) kreativitas. Sifat ini berupa kemampuan untuk bersifat orisinal, memikirkan dengan cara-cara baru (Muflihin, 2018).

Menurut teori sifat, seseorang yang pantas dan layak menjadi seorang pemimpin adalah mereka yang mempunyai sifat kepemimpinan yang dibawa sejak dari lahir. Artinya, pemimpin di sini dilahirkan bukan dipelajari atau diajarkan. Kekurangan pada pendekatan teori sifat ini adalah hanya menjelaskan pemimpin dan kepemimpinan formal. Sementara ada orang yang memang terlahir dengan memiliki ciri-ciri seperti di atas, lantas tidakkah mereka disebut sebagai pemimpin?

Brain Tracy mengidentifikasi tujuh kualitas yang harus dimiliki oleh seorang pemimpin yang baik, yaitu: visi (vision), keberanian (courage), integritas (integrity), 
kerendahan hati (humility), memiliki perencanaan strategis (strategic planning), fokus (focus) dan kerjasama (cooperation) (Tracy, 2016).

Seorang pemimpin yang ideal adalah yang memiliki ciri-ciri berikut: pengetahuan umum yang luas, kemampuan untuk bertumbuh dan berkembang, sifat inkuisitif, kemampuan analitik, daya ingat yang kuat, kapasitas integratif, keterampilan berkomunikasi secara efektif, keterampilan mendidik, rasionalitas, objektivitas, pragmatisme, kemampuan menentukan skala prioritas, kemampuan membedakan mana yang urgen dan penting, rasa tepat waktu, rasa kohesi yang tinggi, naluri relevansi, keteladanan, kesediaan menjadi pendengar yang baik, adaptabilitas, fleksibelitas, ketegasan, keberanian, orientasi masa depan, dan sikap antisipatif (Siagian, 1999).

Jacqueline Whitemore (Whitemore, 2015), berangkat dari perspektif entrepreneur mengemukakan bahwa kualitas kepemimpinan seseorang dapat ditinjau dari tujuh sifat dasar yang meliputi: integrity, passion, accountability, delegation, creativity, communication dan respect. Sementara Tanya Prive (Prive, 2015), mengusulkan sepuluh kualitas pemimpin: honesty, delegate, communicatin, confidence, commitment, creativity, intuition, inspire, dan approach. Brian Downard mengemukakan tujuh kategori kualitas kepemimpinan yang kemudian dipilah lagi dalam bagian yang lebih rinci: personality traits, self awareness, communicate, delegate, agility and adaptability, cultivate wisdom dan effect change (Downard, 2015).

Hal yang tidak kurang pentingnya dari seorang pemimpin tentu saja keterampilan kepemimpinan. Beberapa pakar memberdakan keterampilan ini menjadi keterampilan kepemimpinan personal dan interpersonal. Keterampilan personal untuk mengembangkan kepekaan pribadi, manajemen stres, dan penyelesaian masalah secara kreatif. Sedangkan keterampilan interpersonal digunakan untuk komunikasi yang suportif, mendapatkan kekuasaan dan pengaruh, memotivasi orang lain, dan manajemen konflik (Luthans, 2006).
Teori kedua yang digunakan adalah teori gender. Secara garis besar teori gender terbagi menjadi dua yaitu teori nature dan teori nurture. Menurut teori nature, adanya perbedaan perempuan dan laki-laki merupakan sesuatu yang bersifat kodrati, sehingga harus diterima apa adanya. Perbedaan biologis tersebut memberikan indikasi dan implikasi bahwa di antara kedua jenis kelamin memiliki tugas dan peran yang berbeda. Ada tugas dan peran yang dapat dipertukarkan, namun ada tugas dan peran yang secara kodrati tidak dapat dipertukarkan.

Teori nurture berpendapat bahwa perbedaan perempuan dan laki-laki pada hakekatnya adalah bentukan masyarakat melalui konstruksi sosial budaya, sehingga menghasilkan tugas dan peran yang berbeda. Perbedaan ini menyebabkan perempuan selalu tertinggal dan terabaikan peran dan kontribusinya dalam hidup berkeluarga, bermasyarakat, berbangsa dan bernegara. Konstruksi sosial budaya biasanya menempatkan perempuan dan laki-laki dalam posisi yang berbeda.

Teori gender digunakan untuk mengkaji fenomena yang ditampakkan oleh perempuanperempuan yang memimpin madrasahmadrasah yang ada dalam lembaga pendidikan Islam di Lombok Barat. Bagaimana perjuangannya menggagas, mendirikan, dan mengelola sampai ketahanannya menunjukkan struggle for life di tengah lingkungan yang belum sepenuhnya menerima perempuan sebagai pemimpin madrasah dan berbagai upaya yang dilakukan untuk mempertahankan dan mengembangkan madrasah sehingga tetap eksis sampai sekarang.

Berdasarkan pendapat-pendapat di atas, ada sembilan indikator yang dikembangkan dalam instrumen penelitian untuk mengukur kualitas kepemimpinan perempuan, yaitu kedewasaan emosional, tanggung jawab, perseptif, kemampuan adaptasi, kreativitas, objektif, inisiatif, kemampuan komunikasi dan percaya diri. Tabel 1 dan 2 memberikan informasi terkait temuan lapangan.

Temuan yang berbeda dengan beberapa pendapat yang dikutip tersebut didapatkan pada indikator tanggung jawab pada poin alasan normatif. Ini bisa jadi karena penelitian 
ini dilakukan pada subjek yang sudah paham dengan ajaran agama yang terkait dengan kepemimpinan dan hidup dalam lingkungan pondok pesantren, di mana dalam Islam memang dikatakan bahwa setiap orang adalah pemimpin dan memiliki tanggung jawab terhadap apa yang dipimpinnya. Dengan demikian, menjadi pemimpin bagi subjek penelitian berarti menjalankan salah satu kewajiban agama terkait amanah sebagai khalifah yang harus menciptakan ketertiban, kemakmuran dan kesejahteraan di muka bumi.

Pada indikator kedewasaan emosional didapatkan poin ikhlas berbagi. Seperti halnya tanggung jawab menjadi pemimpin, sikap ikhlas juga merupakan salah satu ajaran agama Islam yang harus ditanamkan dan dikembangkan agar menjadi karakter yang melekat pada diri setiap muslim. Sikap ikhlas tidak saja ketika berbagi atau memberikan apa yang dimiliki, namun juga ketika menerima apa yang diberikan. Jadi dalam Islam keihlasan lebih terkait dengan dimensi spiritual-ilahiyah, rasa yang hanya diketahui oleh yang bersangkutan dan Tuhan.

Dalam konteks penelitian ini, ikhlasnya para kepala madrasah lebih banyak terkait dengan kesiapannya dalam meluangkan waktu terutama di luar jam formal, untuk memberikan bantuan kepada warga madrasah. Tentu juga dalam posisinya sebagai pimpinan di lembaga non-pemerintah, seorang kepala madrasah digaji berdasarkan kemampuan dan kemauan yayasan yang bermakna tidak ada perhitungan tunjangan struktural dalam jumlah yang sudah tetap sebagaimana di madrasah negeri. Jadi ini bersifat fluktuatif, yang seringkali lebih rendah.

Pada indikator percaya diri ditemukan ada seorang kepala madrasah yang selalu tidak percaya diri dalam melakukan sesuatu atau bertemu dengan orang lain. Rasa tidak percaya diri tersebut -sebagaimana pernyataan subjek dan pengamatan peneliti- ternyata disebabkan atau erat kaitannya dengan kondisi dirinya yang penyandang disabilitas (ada masalah dengan sebelah kaki). Ini dapat dinilai sebagai sesuatu yang manusiawi, mengingat tumbuh dan terpeliharanya kepercayaan diri sangat dipengaruhi oleh faktor internal dan eksternal pada diri seseorang. Pemikiran dan penerimaan diri akan membentuk konsep diri yang positif atau negatif. Demikian juga pandangan dan perlakuan lingkungan turut berpengaruh terhadap rasa percaya diri. Pada kasus subjek penelitian, permasalahan itu lebih banyak datang dari dalam dirinya sendiri karena lingkungannya cukup menghargai dan menempatkannya berdasarkan kemampuan yang dimiliki.

Kepemimpian perempuan dalam ruang lingkup lembaga pendidikan (Islam) dan ruang lingkup yang luas, memiliki kelebihan dan kelemahan. Terkait kelebihan kepemimpinan perempuan, penulis cenderung sependapat dengan Hasaje, kepemimpinan perempuan memiliki beberapa kelebihan dari kepemimpinan laki-laki seperti perempuan memiliki kualitas transfomational lebih dari laki-laki; perempuan adalah pembaca emosi yang baik, cepat dan mudah; perempuan selalu ada untuk bawahannya pada situasi apapun; perempuan lebih kreatif karena mereka lebih empati; perempuan lebih baik dalam manajemen konflik karena mereka memiliki kemampuan mendengar dan berkomunikasi yang baik, serta menunjukkan toleransi dan empati yang baik pula; perempuan melihat kepemimpinan sebagai fasilitas, sedang lakilaki melihatnya sebagai memimpin; laki-laki bersifat otokratis, karena lebih percaya dengan kekuatan dari otoritas dan posisi organisasi yang mereka miliki sendiri, sementara perempuan bersifat demokratis dan partisipatori, mereka selalu membagi kekuasaan dan informasi dengan bawahannya (Hesaje, 2013).

Berdasarkan kutipan tersebut dan juga berdasarkan pengalaman penulis, kelebihan yang didapatkan dari kepemimpinan perempuan dapat dibedakan dalam dua garis besar, yaitu berdasarkan fleksibelitas proses dan berdasarkan kinerja. Berdasarkan fleksibelitas proses, kepemimpinan perempuan pada umumnya lebih bersifat lentur jika dibandingkan dengan laki-laki. Selain itu, biasanya pemimpin perempuan lebih perhatian pada kebutuhan bawahannya terutama kebutuhan emosional. Sementara berdasarkan kinerja, kelebihannya terletak pada pekerjaan yang ditangani secara cermat, teliti (detail), dan tepat waktu. Adapun kelemahan dari 
kepemimpinan perempuan adalah efek samping dari kelebihan yang disebutkan di atas. Kelebihan dan kelemahan tersebut akan dikaji lebih lanjut pada uraian di bawah ini (Nurhilaliati, 2018).

Alquran menggariskan manusia (dan makhluk lain serta semua hal yang mengitari interaksi yang terjadi) telah diciptakan secara berpasang-pasangan. Ini dapat dipahami bahwa semua entitas yang ada telah dianugerahi dua sisi berbeda yang saling melengkapi, seperti feminitas dan maskulinitas, atau meminjam istilah Murata, memiliki Yin dan Yang (Murata, 1997). Perempuan dan laki-laki sebenarnya memiliki kedua unsur itu dalam dirinya. Konstruksi budaya dan pembiasaan sehari-hari, umumnya menuntut perempuan memiliki sisi feminitas yang lebih dominan dan laki-laki (bila perlu) harus menegasikannya hingga taraf terendah (Wirawan, 2010).

Terkait prospek kepemimpinan perempuan di lembaga pendidikan Islam ditemukan satu kepala madrasah yang beranggapan bahwa posisinya sebagai kepala madrasah bukanlah prioritas. Artinya sebagai seorang ibu rumah tangga jika suaminya melarang untuk berada di posisi tersebut atau jika harus memilih antara karir dan rumah tangga, dirinya lebih memilih rumah tangga. Pandangan dan sikap ini senada dengan pendapat seorang sumber dari Kemenag Lombok Barat yang beranggapan bahwa minimnya perempuan berada di jajaran pimpinan di lingkungan pondok pesantren karena beberapa alasan, yaitu: (1) kesibukan sebagai ibu rumah tangga yang membuat perempuan merasa kesulitan dalam membagi waktu untuk urusan di rumah dan urusan di madrasah; (2) kecanggungan berkomunikasi, karena lingkungan pondok dan pimpinan pondok didominasi laki-laki, dikhawatirkan bisa menimbulkan fitnah (khalwat); (3) perempuan memang tidak mau karena merasa tidak sanggup menjadi kepala madrasah, sebab untuk menjadi kepala madrasah sekarang persyaratannya berat dan tugasnya juga banyak; (4) Kebijakan pondok pesantren yang memang tidak membolehkan perempuan menjadi kepala madrasah; (5) Tidak ada izin dari suami.
Apabila dikaitkan dengan teori gender, maka kasus ini dapat dipotret dengan teori Nurture yang menjelaskan bahwa pandangan dan sikap subjek penelitian adalah pengaruh konstruksi budaya yang melingkunginya. Sebagaimana diketahui, masyarakat Sasak adalah masyarakat religius yang kental dengan budaya patriarki, yang memosisikan laki-laki sebagai pihak pengambil keputusan.

Sistem kekerabatan pada masyarakat Sasak berdasarkan pada hubungan yang bersifat patrilineal yang diiringi dengan pola menetap patrilocal. Biasanya yang menjadi kepala keluarga dalam rumah tangga adalah suami, dengan kedudukan dan status yang lebih tinggi dan memiliki otoritas yang sangat menentukan dalam pengambilan keputusan (Bartholomew, 2000; Syafruddin, 2013).

Pandangan dan sikap subjek penelitian yang diuraikan di atas, menunjukkan kepatuhan kepada tradisi dan agama. Kelemahan yang terbaca adalah ketidakmampuan melakukan negosiasi antara kepentingan dirinya dengan tradisi. Padahal sebagai seorang yang berpendidikan tinggi dan memiliki pengalaman serta pergaulan yang cukup luas, seharusnya dapat mengambil jalan tengah antara dua pilihan yang sesungguhnya bisa dilakukan bersamaan. Selain itu, konsekuensi logis dari status sebagai khalifah yaitu adanya tugas memberikan pencerahan dan meluruskan pandangan keliru masyarakat awam tentang sesuatu.

Terkait keberterimaan perempuan sebagai kepala madrasah di lingkungan pondok pesantren, sesungguhnya tidak ditemukan penolakan yang ekstrim. Karena beberapa narasumber yang diwawancarai mengatakan, bahwa perempuan dan laki-laki memiliki hak dan kesempatan yang sama untuk menjadi kepala madrasah, selama mereka mampu melakukannya.

Berikut ini merupakan hasil wawancara dengan Musleh, dimana Beliau mengatakan bahwa siapa yang akan menjadi kepala madrasah itu adalah otoritas yayasan untuk menentukannya. Kepala madrasah sekarang memang keponakan dari pendiri pondok ini, namun semua guru dapat menerimanya karena beliau bukan orang baru di sini. Sebelumnya pernah menjadi bendahara madrasah dan guru, 
lalu diangkat menjadi kepala. Di sini ada proses kaderisasi dan penyegaran. Jadi menurut Beliau yang menjadi kepala madrasah tidak mesti keluarga pendiri, karena beberapa kepala sebelum ini adalah bukan pihak keluarga. Berikut wawancara dengan Baharuddin, "Masyarakat Sasak adalah masyarakat paternal, sehingga perempuan lebih diatur oleh laki-laki dan terbangun pandangan bahwa perempuan sebaiknya berada dalam sektor domestik. Ini kemudian berakibat pada lebih banyaknya perempuan yang menekuni pekerjaan dalam rumah tangga dibanding di luar. Keadaan inilah yang menyebabkan SDM perempuan tidak terlalu bagus. Jika diberi kesempatan seperti laki-laki, perempuan juga bisa lebih berkualitas. Kalau memiliki kualitas, kenapa harus melarang perempuan menjadi pemimpin".

Ketika di tanya bagaimana kemampuan perempuan-perempuan yang memimpin madrasah di lingkungan pondok pesantren di Kediri khususnya dan Lombok Barat umumnya, dikatakan oleh Baharuddin, "Memang pada umumnya pemilihan dan penetapan seseorang pada posisi struktural dalam sebuah pondok pesantren ditentukan oleh siapa dirinya. Tentu saja yang diutamakan adalah pemilik dan pendiri pondok. Tapi menurut saya, mereka yang terpilih memang karena memiliki kemampuan”.

Pendapat ini senada dengan yang dikemukakan oleh Zulyadain, "Yang diutamakan dalam kepengurusan dan kepemimpinan di pondok pesantren adalah anak keturunan dan keluarga dekat pemilik dan pendiri pondok. Menurut saya perempuan yang ada di jajaran pemimpin madrasah di pondokpondok di Kediri memang anak keturunan pendiri, namun mereka juga memiliki kemampuan terkait tugas dan perannya".

Pandangan kedua narasumber di atas, tidak terlalu disetujui oleh Rabiatul Adawiyah, "Saya sepakat bahwa perempuan dan laki-laki memiliki hak dan kesempatan yang sama untuk menjadi pemimpin selama dia memiliki kemampuan. Terkait kepemimpinan di pondok pesantren, boleh-boleh saja dari anak keturunan pendiri dan pemilik pondok pesantren yang bersangkutan, juga selama dia mampu. Dalam kasus di Kediri, saya melihat memang kepala madrasah Yusuf Abdussatar dan Selaparang memiliki kemampuan dalam makna pengetahuan dan manajemen untuk menjadi pemimpin. Tetapi untuk di Nurul Hakim, jika kepala madrasah sekarang masih tetap mau berada di posisi itu, harus merubah pendekatan dalam memimpin, dan jangan terlalu lemah-lembut, serta melakukan terobosan baru. Jika tidak mampu berikan kesempatan kepada orang lain yang lebih mampu, meskipun bukan dari anak keturunan pendiri".

Keberterimaan kepala madrasah perempuan di wilayah Lingsar dapat dikatakan cukup baik juga. Menurut narasumber yang diwawancarai, tidak ada yang mempermasalahkan siapapun dari perempuan maupun laki-laki yang menjadi pimpinan madrasah, meskipun prioritas utama adalah anak keturunan pendiri dan pemilik pondok. Demikian dikatakan oleh Muhammad Tajun Toyib, "Yang diprioritaskan untuk menjadi unsur pimpinan pada madrasah di lingkungan pondok (kami) adalah anak keturunan pendiri dan pemilik pondok. Pendiri Darunnajah adalah ayah saya. Sebelumnya saya juga pernah menjadi kepala MI, kemudian digantikan oleh ibu Komalawati (PNS) yang diperbantukan oleh Kemenag Lombok Barat di Yayasan. Ibu ini bukan dari pihak keluarga. Sekarang kakak saya (Iklima) menjadi kepala MA. Tapi menurut saya posisi beliau tepat di situ, karena kualifikasi pendidikannya adalah magister pada bidang Manajemen Pendidikan. Selain itu saya melihat Beliau sangat tegas dan berani serta menerapkan open management".

Pendapat tersebut memang diberikan oleh adik kandung kepala MA yang bisa saja sarat subjektivitas. Namun ketika dilakukan triangulasi sumber diketahui bahwa pernyataan di atas objektif. Ini didukung juga oleh pembantu peneliti, bahwa ketika ingin melakukan wawancara dengan pihak tenaga pendidik, kepala madrasah mempersilahkan untuk memilih dan menentukan sendiri tenaga pendidik mana yang ingin diwawancarai. Dengan demikian kepala MA ini tidaklah "menjaga" image atau membuat-buat cerita supaya kelihatan bagus. Sehingga objektivitas informasi yang diperoleh cukup terjaga. 
Sementara itu, penilaian masyarakat yang ada di sekitar Pondok Pesantren AsSullamy menunjukkan adanya keraguan terhadap kepemimpinan perempuan di sana, terutama terhadap kepala MA. Keraguan ini muncul karena kepala MA masih sangat muda dan merupakan putri dari ketua yayasan, sebagaimana dikatakan oleh Solihin, "Pada prinsipnya tidak masalah apakah yang memimpin perempuan atau laki-laki. Tetapi sebaiknya laki-laki yang diberikan kesempatan, karena perempuan banyak kesibukannya sebagai ibu rumah tangga. Namun jika mampu saya lebih memilih yang mempunyai kemampuan, baik perempuan maupun laki-laki. Tentang kepala MA, saya dengar-dengar sudah cukup bagus. Tetapi saya sedikit ragu karena dia masih sangat muda dan masih banyak yang lebih senior. Apa karena putrinya ketua yayasan atau karena kemampuan, saya tidak tahu persis. Mudahan saja karena kemampuan, sebab setau saya dia lagi kuliah S2".

Kondisi yang sama dari terpilihnya kepala madrasah perempuan di lingkungan pondok pesantren di atas, adalah karena mereka merupakan anak keturunan dan keluarga langsung dari pendiri dan pemilik pondok. Meskipun menurut beberapa narasumber yang diwawancarai, terpilihnya mereka karena memiliki kemampuan. Akan tetapi itu tidak dapat menghentikan orang luar untuk berkomentar negatif. Karena itu, untuk menghindarinya, memang sudah seharusnya pondok pesantren mengimplementasikan manajemen dan tata kelola yang modern dan profesional (diteliti lebih lanjut).

Selain kualitas serta keberterimaan kepala madrasah perempuan yang telah dipaparkan di atas, berikut dikemukakan beberapa capaian yang merupakan kinerja para kepala madrasah, yang belum pernah dilakukan oleh kepala madrasah sebelumnya. Ini dapat dijadikan indikator dan pertimbangan, bahwa perempuan-perempuan ini memiliki kemampuan untuk membawa perubahan positif bagi lembaga.

\section{PENUTUP}

Kepemimpinan kepala madrasah perempuan di Kabupaten Lombok Barat dapat dikategorikan memiliki kualitas yang cukup baik. Berdasarkan sembilan indikator yang digunakan, diketahui bahwa terdapat tujuh indikator yang muncul pada semua (tujuh) subjek penelitian yaitu kedewasaan emosional, objektif, perseptif, adaptasi, inisiatif, kreativitas, dan skill berkomunikasi. Indikator tanggung jawab tidak muncul secara maksimal pada satu subjek penelitian. Demikian juga indikator percaya diri. Perempuan memiliki prospek yang baik untuk berada di posisi pimpinan madrasah, karena memiliki kualitas kepemimpinan. Namun prospek ini perlu didialogkan dengan konstruksi sosial budaya/pandangan masyarakat yang beranggapan bahwa perempuan tidak terlalu mampu menjadi pemimpin. prospek ini dapat juga dilihat dari keberterimaan kepala madrasah perempuan yang cukup baik.

Temuan penelitian ini dapat digunakan untuk mengembangkan Traith Theory of Leadership yang mengatakan bahwa seorang dapat disebut sebagai pemimpin karena memiliki sifat-sifat tertentu seperti: integrity, passion, accountability, delegation, creativity, communication dan respect (Whitemore. J, 2015). Atau honesty, delegate, communication, confidence, commitment, creativity, intuition, inspire, dan approach (Prive. T, 2015). Dan personality traits, self awareness, communicate, delegate, agility and adaptability, cultivate wisdom dan effect change (Brian D, 2015). Indikator-indikator yang disebutkan di atas menurut peneliti belum mampu melahirkan pemimpin paripurna seperti yang digariskan dalam Islam, namun baru memiliki dimensi humanishorisontal yang belum dikaitkan dengan dimensi spiritual-vertikal. Konsep manusia yang diyakini dalam Islam adalah makhluk yang berdimensi paripurna, karena kesempurnaan potensi yang dianugerahkan Allah yang kebermaknaannya dapat ditemukan dalam keseimbangan hubungan dengan Tuhan, dirinya, lingkungan sosial, dan lingkungan alam. Pemimpin sebagai salah satu unsur bermasyarakat harus memiliki kemampuan tersebut. Untuk itu para pemimpin umumnya dan dalam lembaga pendidikan Islam khususnya harus pula ditambahkan dengan indikator ikhlas dan pemahaman yang baik terhadap landasan 
normatif menjadi seorang pemimpin. Perempuan memiliki kans besar untuk menjadi pimpinan dalam lembaga pendidikan karena memiliki sifat-sifat yang jarang ditemukan pada laki-laki, seperti kesabaran, mengurus orang lain, kelembutan, dan semacamnya.

\section{DAFTAR PUSTAKA}

Anna G (2016) Gender Differences in Leaderships. Available at: https://www. researchgate.net/publication.

Bailey, S. (2014) Who Makes A Better: A Man or A Women. Available at: https://www.forbes.com (Accessed: 10 April 2017).

Bartholomew, J. R. (2000) Ali Lam Mim Kearifan Masyarakat Sasak. Edited by I. Rosyidi. Yogyakarta: Tiara Wacana.

Bush, Tony; Coleman, M. (2006) Leadership and Management in Education. Yogyakarta.

Downard, B. (2015) 101 Best Leadership Skills, Traits \& Qualities - the Complete List. Available at: briandownard.com\%3Eleadership.

Eagly, A. H. (2007) Female Leadership Advantage and Disadvantage Resolving the Contradiction.

Helgesen, S. (1995) The Female Advantage: Women Ways of Leadership. New York: Doubleday Dell Publishing Group, Inc. Available at: https://www.amazon.com.

Hesaje, H. (2013) 'Female Leadership: An Exploratory Research from Lebanon', American Journal of Scientific Research, (Issue 86 March, 2013).

Jirasinghe, D. G. L. (1996) The Competent Had: A Job Analysis of Heads Task Personality Fasctor. Amazon: Roudledge.

Luthans, F. (2006) Perilaku Organisasi. Yogyakarta: Andi.

Marshall, Catherine; Rossman, G. B. R. (1995) Designing Qualitative Research. 2nd ed. London: SAGE Publication.

Mufidah (2010) Bingkai Sosial Gender.
Malang: UIN Malang Press.

Muflihin, M. H. (2018) 'Kepemimpinan Pendidikan: Tinjauan terhadap Teori Sifat dan Tingkah-laku', INSANIA : Jurnal Pemikiran Alternatif Kependidikan, 13(1), pp. 67-86. doi: 10.24090/insania.v13i1.286.

Murata, S. (1997) The Tao of Islam. Bandung: Mizan.

Nurhilaliati, N. (2018) Kepemimpinan Perempuan dalam Lembaga Pendidikan Islam (Studi Kasus pada Pondok Pesantren Al-Ikhlas Ranggo Pajo Doтри NTB).

Prive, T. (2015) Top Ten Qualities that Make A Great Leader. Available at: https://www.forbes.com.

Shanmugam, Menaha; Amaratunga, R.D.G; Haigh, R. P. (no date) Leadership Styles: Gender Similarities, Differnces and Perceptions. Available at: https://www.irbnet.de/daten/iconda.

Siagian, S. P. (1999) Teori dan Praktek Kepemimpinan. Jakarta: Rineka Cipta.

Stainback, S. S. (1988) Understanding \& Conducting Qualitative Research. Virginia: Kendall/Huns.

Sugiyono (2010) Metode Penelitian Pendidikan: Pendekatan Kuantitatif, Kualitatif dan $R \& D$.

Suralaga, F. (2003) "Pendahuluan", in Pengantar Kajian Gender. Jakarta: PSW IAIN Syahid Kerjasama dengan McGill Project/IIESP.

Syafruddin (2013) Perceraian Orang Sasak (Dimensi Sosial Budaya). Mataram: IKIP Press.

Tracy, B. (2016) The Seven Leadership Qualities of All Great Leader. Available at: https://www.entrepreneur.com.

Tracy, B. (no date) The Seven Leadership Qualities of Good Leadership. Available at: https://www.briantracy.com.

Veithzal Rivai, A. A. (2009) Islamic Leadership: Membangun Super Leadership melalui Kecerdasan Spiritual. 
Wahid, A. (2010) Menggerakkan Tradisi. Wirawan, S. (2010) Pengantar Psikologi Yogyakarta: LKiS.

Umum. Jakarta: Raja Grafindo Persada.

Whitemore, J. (2015) Seven Qualities that Distinguish Genuine Leaders from Bossy Poseurs. Available at: https://www.entrepreneurship.com. 